\title{
ENGINEERING SCIENCES
}

\section{МЕТОДИКА ВИЗНАЧЕННЯ НОМІНАЛУ НАВІСНИХ ЕЛЕМЕНТІВ ШЛЕЙФІВ НЕАДРЕСНОЇ ПОЖЕЖНОЇ СИГНАЛІЗАЦІї}

\author{
${ }^{1}$ Терлецький T. В., канд. техн. наук, доцент, ORCID: 0000-0002-4114-0734, \\ ${ }^{2}$ Кайдик О. Л., канд. техн. наук, дочент, ORCID: 0000-0002-3620-270X, \\ ${ }^{\text {I}}$ Свсюк М. М., канд. техн. наук, доиент, ORCID: 0000-0002-3768-8959, \\ ${ }^{1}$ Ткачук А. А., канд. техн. наук, ORCID: 0000-0001-9085-7777, \\ ${ }^{3}$ Сомов Д. О., канд. техн. наук, доцент, ORCID: 0000-0001-2034-8579, \\ Украӥна, м. Луиьк, Луцький національний технічний університет \\ ${ }^{1}$ Кафедра електроніки та телекомунікаиій \\ ${ }^{2}$ Кафедра приладобудування \\ ${ }^{3}$ Кафедра прикладної механіки
}

DOI: https://doi.org/10.31435/rsglobal_sr/28022020/6953

\section{ARTICLE INFO}

Received 18 December 2019

Accepted 13 February 2020

Published 28 February 2020

\section{KEYWORDS}

fire detector, loop fire alarm, resistance, mode of operation, fire alarm control panel, verification, nomogram.

\begin{abstract}
The fire alarm system shall detect the initial signs of fire at an early stage of its occurrence and shall not give false positives. It also depends on balancing the fire alarm loop with the fire receiving control device. The use of devices from different manufacturers in the construction of a fire alarm may result in the malfunctioning of such a system and giving false signals.

The article presents the results of the analysis of the state of non-address fire control receivers of different manufacturers, depending on the mode of the fire alarm loop, in which he may be. The received generalized nomogram of states of non-address control devices depending on the resistance of the fire plume is presented. A method for determining the resistance of loop elements against different fire detectors is proposed and an appropriate algorithm is developed.
\end{abstract}

Citation: Терлецький Т. В., Кайдик О. Л., Свсюк М. М., Ткачук А. А., Сомов Д. О. (2020) Metodyka Vyznachennia Nominalu Navisnykh Elementiv Shleifiv Neadresnoi Pozhezhnoi Syhnalizatsii. Science Review. 2(29). doi: 10.31435/rsglobal_sr/28022020/6953

Copyright: (C 2020 Терлецький Т. В., Кайдик О. Л., Свсюк М. М., Ткачук А. А., Сомов Д. О. This is an open-access article distributed under the terms of the Creative Commons Attribution License (CC BY). The use, distribution or reproduction in other forums is permitted, provided the original author(s) or licensor are credited and that the original publication in this journal is cited, in accordance with accepted academic practice. No use, distribution or reproduction is permitted which does not comply with these terms.

Застосування на об'єктах різного призначення таких інформаційно-вимірювальних систем (IBC), як системи пожежної сигналізації (СПC) та оповіщення, обумовлено необхідністю забезпечення пожежної безпеки будівель, споруд та приміщень з масовим перебуванням людей, а також тих, що не контролюються обслуговуючим персоналом (безлюдні виробництва) та мають потенційні джерела запалювання або вибухонебезпечний осередок.

До складу СПС та оповіщення входять пожежний приймально-контрольний прилад (ППКП), шлейфи, до яких підключено сповіщувачі пожежні (СП), оповіщувачі пожежні та устаткування електроживлення.

Вимоги до застосування СПС регламентується багатьма нормативно-технічними документами. Так у п.1.6 стандарту EN 54-1:2014 [1] є вимога що до сумісності СП та ППКП: "Те, що компонент системи задовольняє вимогам відповідної частини EN 54, не означає того, що такий компонент буде обов'язково правильно функціонувати спільно з іншим компонентом, який також задовольняє вимогам відповідної частини EN 54 (наприклад, ППКП у сполученні 3 
СП), якщо тільки обидва компонента не були оцінені разом як ті, що задовольняють вимогам щодо системи". Окрім цього, відповідно до п.7.2.1 ДБН В.2.5-56:2014 [2], СПС повинна виявляти ознаки пожежі на ранній стадії та не давати хибних спрацювань, а це залежить і від збалансування ШПС з ППКП, що здійснюється за відповідних номіналів кінцевого, обмежуючого та шунтуючого резисторів.

Кожен із виробників ППКП і СП у технічній документації наводить свої методики та рекомендації щодо визначення значень навісних елементів ШПС. На практиці ж не завжди вдається відразу досягнути збалансування ШПС й ППКП. Розраховане за поданою в документації на ППКП методикою значення може відрізнятись від необхідного номіналу опорів, якщо СП в ШПС використано інших виробників. Це пояснюється п.1.6 національного стандарту ДСТУ EN 54-1:2014 і тим, що сучасні СП - це активні елементи IBC, що мають не однакові вольт-амперні характеристики.

3 огляду на викладене вище, постало питання в розробці методики визначення номіналу кінцевих опорів ШПС стосовно різних типів ПС і марок неадресних ППКП.

Усі неадресні ППКП визначають стан ШПС шляхом вимірювання сумарного опору підключеного шлейфа зі встановленими у ньому СП та кінцевим елементом [3-5, 12]. Ці стани ШПС і самого приладу відображаються на світлодіодних індикаторах ППКП.

Умови формування відповідних режимів роботи ППКП у кожного виробника різний і залежить від конструктивних особливостей приладу.

За реакцією СП на появу первинних ознак пожежі їх можна поділити на дві групи: нормально-замкнуті та нормально-розімкнуті, які до ППКП підключають за двохпровідною або чотирьох-провідною схемами [6-11]. Найбільше розповсюдження отримала двохпровідна схема.

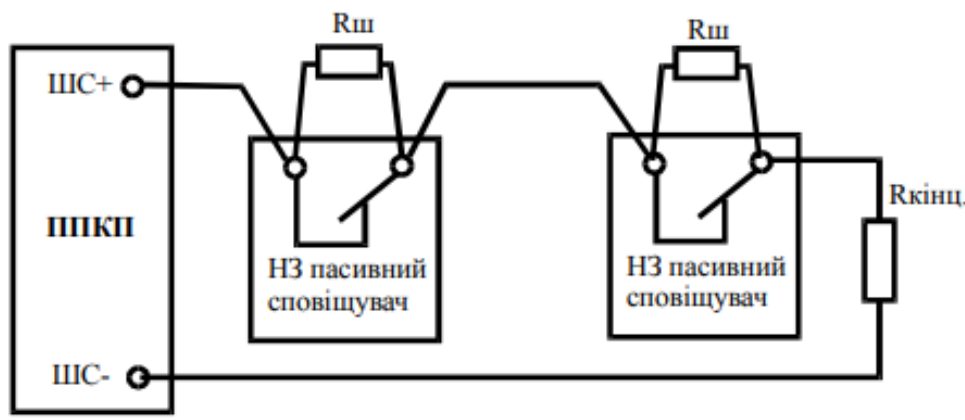

Рис. 1. Схема підключення нормально-замкнених СП в двохпровідний шлейф

$$
R_{\text {кіни }} \text { - кінцевий резистор }
$$

Сповіщувачі із нормально-замкнутими контактами включають у двохдротовий шлейф послідовно (рис. 1). У черговому режимі шлейф перебуває під напругою та через нього протікає визначений струм, який прийнято називати черговим. Під час спрацьовування одного або декількох сповіщувачів черговий струм миттєво падає до нуля, що і $є$ ознакою пожежі. Такий спосіб визначення факту спрацювання сповіщувача має суттєвий недолік: обрив шлейфа сприймається як пожежа. Обрив шлейфу повністю виводить систему з ладу. Для усунення даного недоліку застосовують шлейфи із шунтуючими (обвідними) резисторами (рис. 2), який встановлюють паралельно до вихідних контактів кожного нормально-замкненого СП.

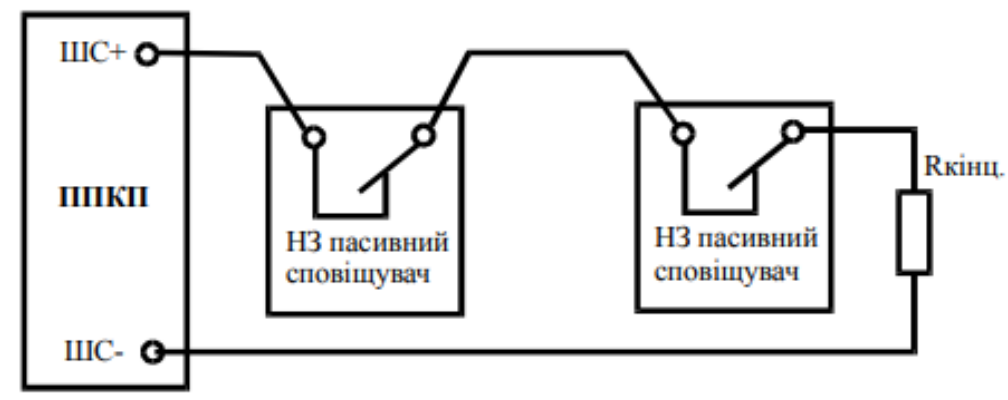

Рис. 2. Схема підключення нормально-замкнених СП з шунтуючим резистором в двохпровідний шлейф $R_{u}-$ шунтуючий резистор 
У черговому режимі значення струму визначається опором кінцевого елементу або кінцевого пристрою, так як опір контактів сповіщувача значно менший за опір шунтуючого резистора, то струм проходить через контакти СП. Уразі спрацьовування сповіщувача його контакти розмикаються і струм починає протікати через шунтуючий резистор. В наслідок чого його величина зменшується за рахунок підвищення сумарного опору ШПС. За величиною зменшення струму можна визначити не тільки факт спрацьовування сповіщувача, але й кількість сповіщувачів, що спрацювали в шлейфі. Під час обриву шлейфа струм падає до нуля. Дана схема підключення дозволяє ідентифікувати такі несправності, як обрив лінії та коротке замкнення.

Принцип дії кожного СП та вхідний опір в різних режимах роботи зазначено в його технічному паспорті.

Пасивні СП з нормально-розімкненими контактами підключають до двохдротового шлейфу паралельно (рис. 3). У такій схемі послідовно до кожного СП встановлюють навантажувальний резистор $R_{\mathrm{H}}$. Уразі спрацьовування сповіщувача відбувається замикання його контактів і струм починає протікати через замкнені контакти та резистор $R_{\mathrm{H}}$. Внаслідок цього струм у шлейфі змінюється, що визначається ППКП як сигнал "Пожежа".

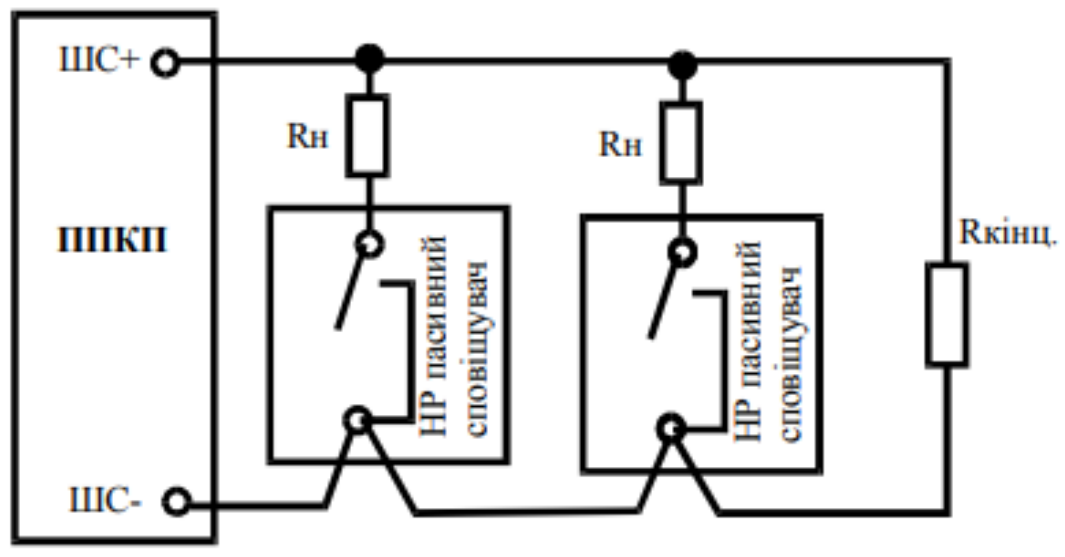

Рис. 3. Схема підключення нормально-розімкнених СП в двопровідний шлейф

$R_{н}$ - резистор навантаження

Весь діапазон опорів, які може прийняти ШПС неадресних ППКП розподілений на три основні області (рис. 4): “Тривога 1" - опір шлейфа прямує до 0; “Черговий режим” та “Тривога 2 ” - опір шлейфа прямує до $\infty$. Кожна із областей “Тривога” складається з трьох підобластей: "Увага", "Пожежа" і "Несправність".

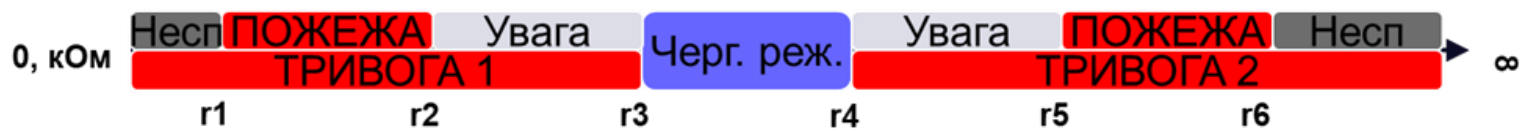

Рис. 4. Стани неадресних ППКП залежно від опору ШПС

У черговому режимі, коли жоден із СП не виявив первинної ознаки пожежі, ППКП фактично визначає опір ШПС, який повинен перебувати в діапазоні від $R 3$ до $R 4$ (іншими словами - номінальне значення кінцевого опору має перебувати у зазначених межах, а вразі виходу за них відбудеться перехід до режиму “Тривога” і спрацювання СПС).

Наявність трьох підобластей режиму “Тривога" пояснюється потребою СПС в розширеній інформативності подій, що відбуваються у контрольованій зоні.

Шлейфи неадресних СПС можуть функціонувати в одному 3 двох режимів роботи однопороговому або двохпороговому. У двохпороговому режимі, у разі спрацювання одного СП, у шлейфі ППКП подає сигнал "Увага", а при спрацюванні двох СП - сигнал "Пожежа". У однопороговому режимі у разі спрацювання одного СП у шлейфі ППКП подає сигнал "Пожежа".

Отриману номограму (див. рис. 4) пропонується використовувати для визначення необхідних умов, виконання яких забезпечить надійність функціонування такої IBC як СПС.

Одним з етапів проектування СПС $є$ побудова ШПС, яка передбачає вибір навісних елементів (опорів), що залежить від властивостей СП і ППКП. Правильність цього вибору забезпечить збалансування ШПС з ППКП та достовірність визначення ППКП стану ШПС. 
У випадку застосування ПС з нормально-замкнутими контактами загальний опір ШПС, у разі їх спрацювання, завжди становитиме більше значення опору кінцевого резистора шлейфу (див. рис. 2).

Еквівалентну електричну схему ШПС із тепловими $\mathrm{CП}_{1} \ldots \mathrm{C}_{\mathrm{n}}$ подано на рис. 5. Значення кінцевого резистора ШПС залежить від конструктивних властивостей конкретної моделі ППКП, закладених в нього під час його проектування, і в ідеалі (відповідно до рис. 4) має відповідати середньому значенню діапазону опорів зони "Черговий режим":

$$
R_{\text {кінц }}=(r 3+r 4) / 2 \text {, }
$$

де $r_{3}$ i $r_{4}-$ відповідно крайня нижня та верхня межа опору ШПС зони “Черговий режим".

Оскільки, резистори випускають відповідно до прийнятого стандартного ряду - то на практиці їх номінал потрібно обирати з найближчого значення ряду до розрахункового.

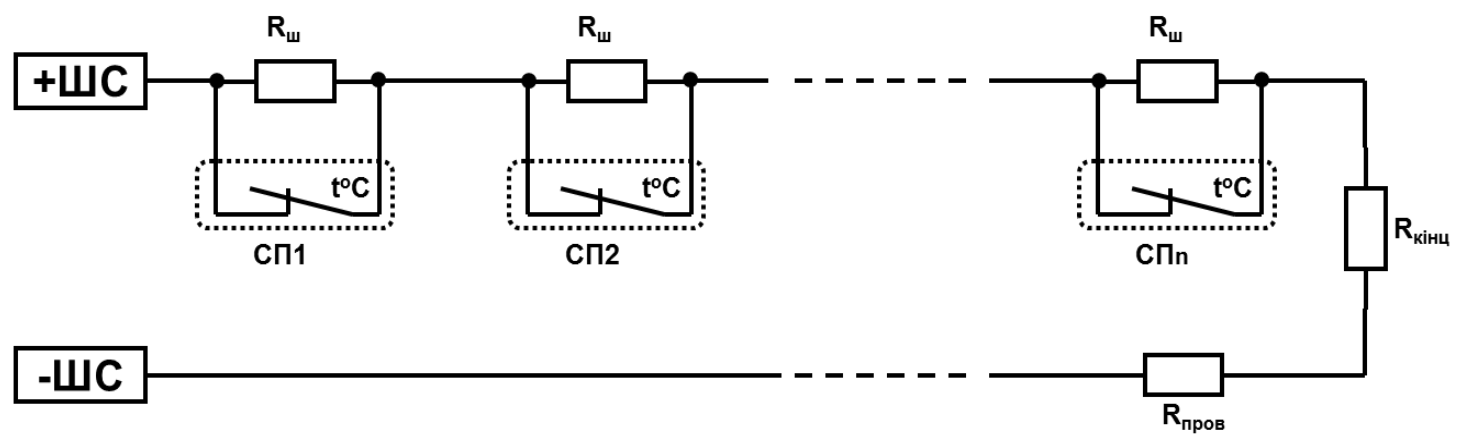

Рис. 5. Еквівалентна електрична схема ШПС з нормально-замкнутими тепловими СП

$$
R_{\text {пров }} \text { - допустимуй погонний опір провідника }
$$

Максимально допустимий погонний опір проводів $R_{\text {пров }}$ ШПС залежить від властивостей ППКП і завжди вказується в його технічному паспорті.

Опір $R_{\mathrm{\amalg}}$ визначає поріг спрацювання СПС та тип режиму роботи ШПС (одно- або двохпороговий).

У випадку досягання порогового значення контрольованого параметра (у даному випадку температура) середовища чутливий комутуючий елемент (термореле) СП розмикається і як

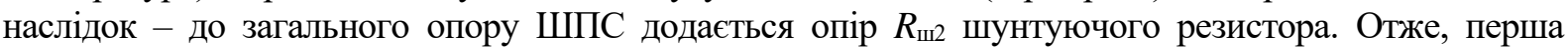
умова, яка повинна виконуватись за двохпороговому режимі роботи ШПС:

$$
r 4<R_{\text {ш2 }}+R_{\text {кінц }}+R_{\text {пров }}<r 5 .
$$

У подальшому, при верифікації за двома СП, до загального опору ШПС додається ще один опір шунтуючого резистора другого СП і відповідно має виконуватись друга умова:

$$
R 5<2 R_{\text {ш2 } 2}+R_{\text {кінц }}+R_{\text {пров }}<r 6 .
$$

Оскільки, максимально допустимий погонний опір провідників $R_{\text {пров }}$ ШПС є досить малою величиною (відповідно до технічних паспортів [3-5] різних виробників ППКП порядка $0,2 \ldots 0,25$ кОм), а опір ШПС у відповідному стані ППКП має перебувати в усередному значенні цього діапазону, то нерівності (2) і (3) можна спростити та перейти до рівняння визначення номіналу $R_{\text {ш }}$ шунтуючого опору.

Двохпороговому режиму роботи ШПС СПС відповідає значення шунтуючого опору, яке можна визначити із наступної залежності:

Звідси:

$$
R_{\text {ш2} 2}+R_{\text {кінц }}=(r 4+r 5) / 2 .
$$

$$
R_{\text {ш2 }}=[(r 4+r 5) / 2]-R_{\text {кінц }} \cdot
$$

Розрахункове значення $R_{\text {ш }}$ шунтуючого опору за (5) у подальшому необхібно привести до нормального ряду опорів, а отримане значення перевірити на виконання умов за (2) i (3).

Одопороговому режиму роботи ШПС СПС відповідає значення шунтуючого опору $R_{\mathrm{m}}$, визначене із наступної залежності:

$$
R_{\mathrm{W} 1}+R_{\text {кінц }}=(r 4+r 6) / 2 .
$$


Звідси:

$$
R_{\mathrm{ml}}=[(r 4+r 6) / 2]-R_{\text {кінц }} \cdot
$$

Розрахункове значення $R_{\text {ш1 }}$ шунтуючого опору за (7) у подальшому потрібно привести до нормального ряду опорів, а отримане значення перевірити на виконання наступної умови:

$$
r 4<R_{\text {ш1 }}+R_{\text {кінц }}+R_{\text {пров }}<r 6 .
$$

Розрахунок навісних елементів ШПС із ПС з нормально-розімкнутими контактами відрізняється від наведеної методики. Загальний опір ШПС у разі їх спрацювання завжди становить менше значення опору кінцевого резистора шлейфу (див. рис. 3).

Еквівалентна електрична схема ШПС із димовими сповіщувачами типу СПД-3 подано на рис. 6.

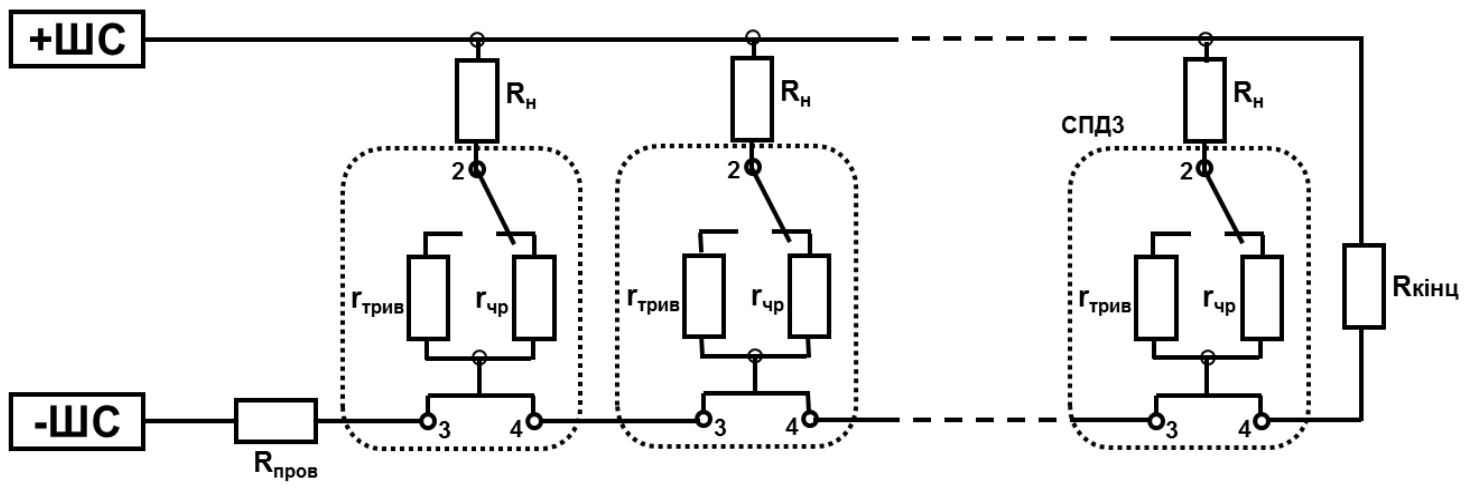

Рис. 6. Еквівалентна електрична схема ШПС з нормально-розімкнутими димовими СП $r_{\text {чр }}$-опір СП в черговому режимі; $r_{\text {трив }}$-опір СП в режимі тривоги

Опір $R_{\text {н }}$ визначає поріг спрацювання IBC та тип режиму роботи ШПС (одно- або двохпороговий).

У черговому режимі опір СП дуже малий по відношенню до номіналу $R_{\text {кінц кінцевого }}$ резистора і значення опору ШПС перебуває в межах $r 3 \ldots r 4$ діапазону “Черговий режим”.

Димові СП, встановлені в ШПС, вимірюють стан задимленості навколишнього середовища та, у разі виявлення первинних ознак пожежі, стрибкоподібно змінюють свій вхідних опір. У

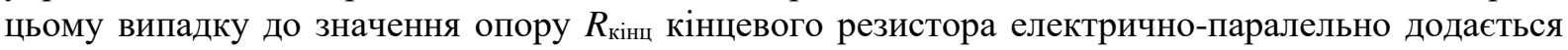
два послідовно з'єднаних опори $R_{\mathrm{H}}+r_{\text {трив}}$.

Еквівалентну електричну схему ШПС під час спрацювання двох СП подано на рис. 7.

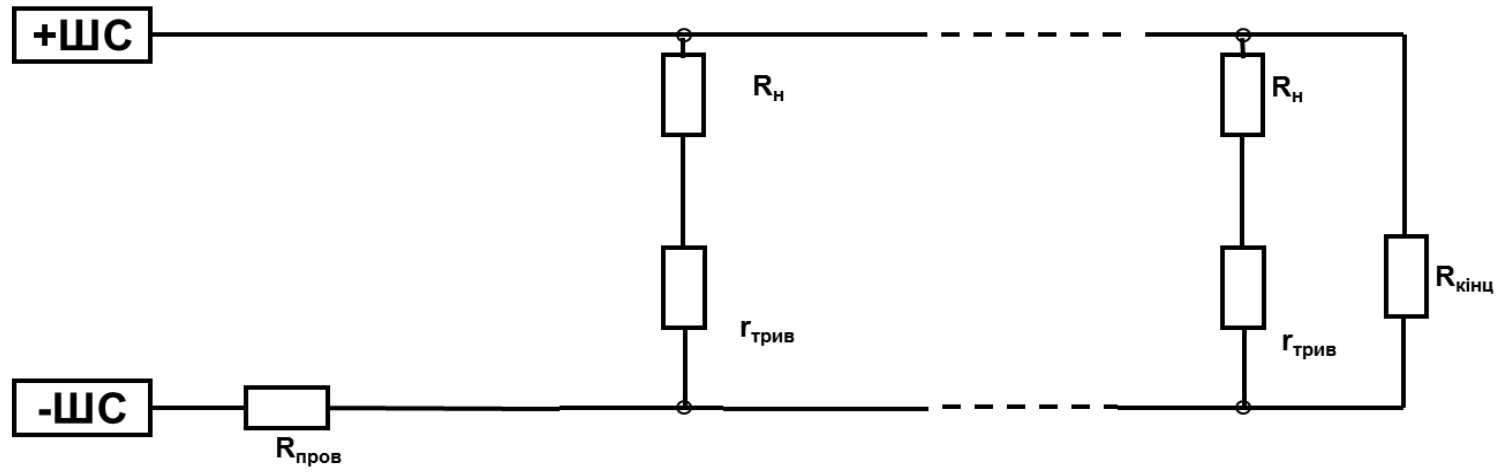

Рис. 7. Еквівалентна електрична схема ШПС під час спраџңювання двох димових СП з нормально- розімкнутими контактами

Для верифікації за двома СП необхідно виконати почергово такі умови:

$$
\begin{gathered}
\frac{1}{r 2}<\frac{1}{R_{н}+r_{\text {трив }}}+\frac{1}{R_{\text {кіни }}}+R_{\text {пров }}<\frac{1}{r 3} ; \\
\frac{1}{r 1}<2 \frac{1}{R_{н}+r_{\text {трив }}}+\frac{1}{R_{\text {кіни }}}+R_{\text {пров }}<\frac{1}{r 2} .
\end{gathered}
$$


Оскільки, максимально допустимий погонний опір провідників $R_{\text {пров }}$ ШПС досить мала величина, і опір ШПС у відповідному стані ППКП має перебувати в усередному значенні цього діапазону, то нерівності (9) і (10) можна спростити та перейти до рівняння, 3 якого у подальшому буде визначено номінал $R_{\text {н }}$ опору навантаження:

$$
\frac{1}{R_{н}+r_{\text {трив }}}+\frac{1}{R_{\text {кіни }}}=\frac{1}{\frac{r 3+r 2}{2}}
$$

Якщо прийняти, що $(r 3+r 2) / 2=r_{\mathrm{cep}(2--3)}$, а також трансформувати рівняння (11) отримаємо:

$$
R_{н}=\frac{r_{\text {сер }_{(\mathrm{r} 2 \mathrm{-} \mathrm{3})}} R_{\text {кіни }}}{r_{\text {сер (12-13) }}+R_{\text {кіни }}}-r_{\text {трив }} .
$$

Однопороговому режиму роботи ШПС відповідає значення опору навантаження визначене з наступної залежності:

$$
\frac{1}{r 1}<\frac{1}{R_{н}+r_{\text {трив }}}+\frac{1}{R_{\text {кіни }}}+R_{\text {пров }}<\frac{1}{r 3} .
$$

Звідси:

$$
R_{H}=\frac{r_{c e p(r 1-r 3)} R_{\text {кіни }}}{r_{\text {cep }(r 1-r 3)}+R_{\text {кіни }}}-r_{\text {трив }} .
$$

За висвітленою вище методикою розрахунку номіналу навісних елементів ШПС розроблено відповідний алгоритм, який подано на рис. 8.

Оскільки, кожен СП має свій внутрішній опір, то для збалансування ШПС iз відповідними режимами роботи ППКП необхідно враховувати й максимальну їх кількість, які можна включити до ШПС.

Випадку, коли ШПС, внаслідок великої кількості СП 3 нормально-замкнутими контактами, активізує режим "Увага" (див. рис. 4) ППКП відповідає наступна умова:

$$
R_{\text {кіни }}+N_{\max } R_{u}<\frac{r 4+r 5}{2} .
$$

Звідси, за наступним рівнянням, можна визначити максимальну кількість $N_{\max }$ сповіщувачів із нормально-замкнутими контактами:

$$
N_{\max }=\frac{\frac{r 4+r 5}{2}-R_{\text {кіни }}}{R_{u}}-1 .
$$

Іншому випадку, коли ШПС, побудовано на СП з нормально-розімкнутими контактами, у разі зняття СП з його бази активізується режим “Несправність" (див. рис. 4) ППКП, оскільки, сумарний опір ШПС стрибкоподібно зростає. Збільшення кількості СП в ШПС призводить до зміщення робочої точки згаданого режиму в сторону режиму "Пожежа". Для того, щоб уникнути входження ШПС в режим "Пожежа", за відповідної кількості СП, при знятті із бази одного СП необхідно забезпечити наступну умову:

$$
\frac{R_{H}+R_{\text {пров }}}{N}>r 6 .
$$

Звідси:

$$
N_{\max }=\frac{R_{H}+R_{n p o s}}{r 6}-1 .
$$

Отримане значення $N_{\max }$ із (18) забезпечить, уразі вилучення СП 3 нормальнорозімкнутими контактами із бази, індикацію ППКП стану ШПС як “Несправність”. 


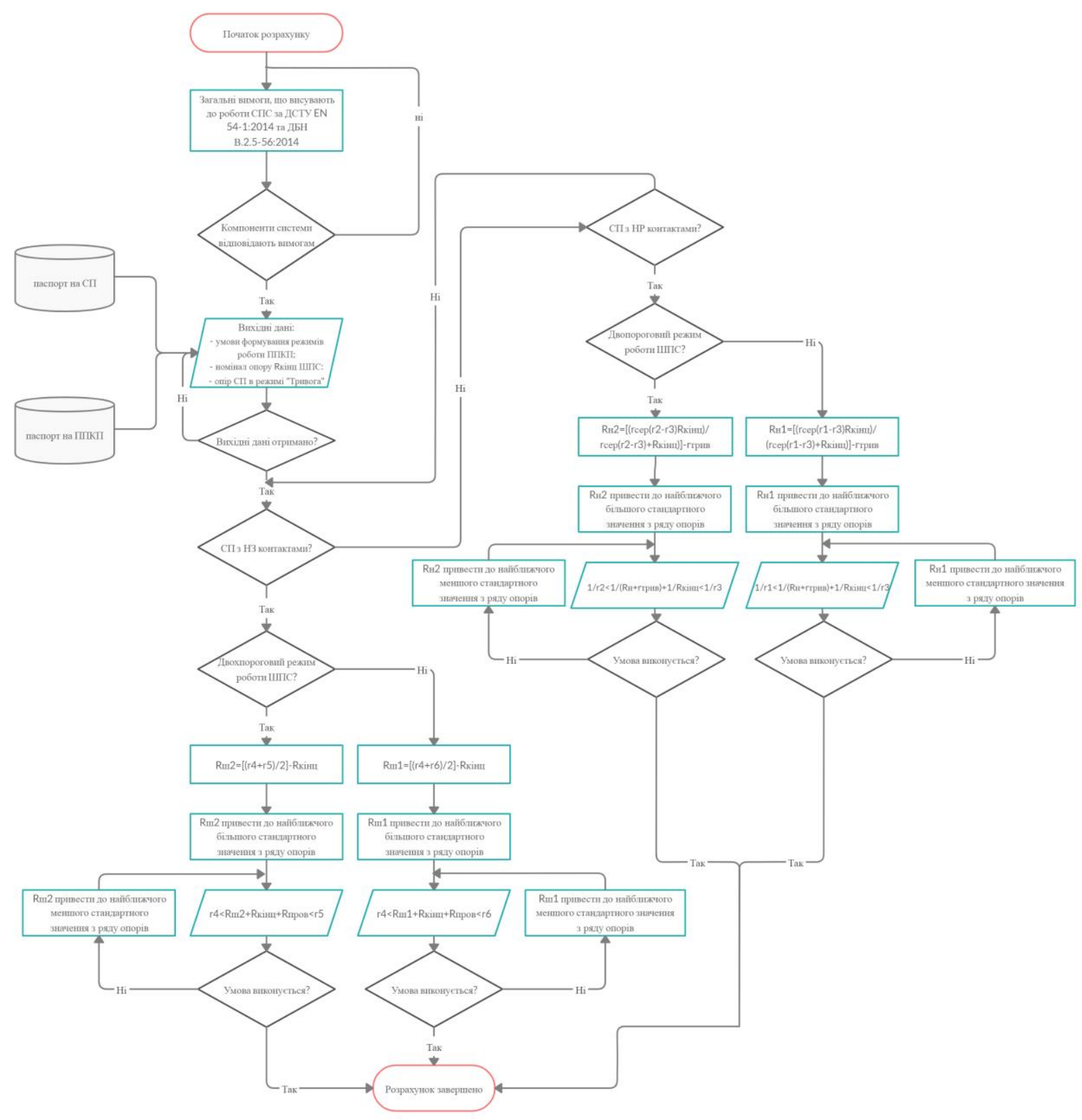

Рис. 8. Алгоритм проведення розрахунку навісних елементів ШПС

Отже, у всіх неадресних ППКП діапазон опорів, які може прийняти ШПС складається із трьох основних областей (“Тривога 1" - опір шлейфа прямує до 0; “Черговий режим” та “Тривога 2"

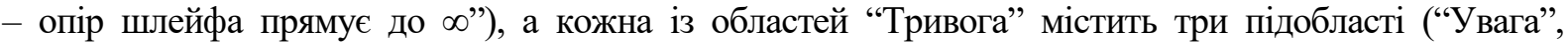
"Пожежа" i “Несправність"), що ілюструє отримана узагальнена номограма (див. рис.4) станів ШПС.

Встановлено, що у випадку застосування ПС із нормально-замкнутими контактами загальний опір ШПС, у разі їх спрацювання, завжди буде більше значення опору кінцевого резистора шлейфу і для правильного функціонування ШПС з верифікацією за двома ПС необхідно забезпечити виконання двох умов (2) і (3). Номінали навісних елементів ШПС зі СП, які мають нормально-замкнуті контакти, можна визначити за (5) та (7).

Розрахунок навісних елементів ШПС із ПС різних виробників 3 нормальнорозімкнутими контактами потрібно здійснювати за (12) i (14), а отримані значення мають відповідати умовам (9), (10) та (13). Загальний опір ШПС у разі їх спрацювання завжди становитиме менше значення опору кінцевого резистора шлейфу.

Оскільки, кожен СП має свій внутрішній опір, то для збалансування ШПС за відповідними режимами роботи ППКП необхідно враховувати і максимальну можливу їх кількість, що можна включити до ШПС за (16) і (18). 


\section{REFERENCES}

1. DSTU EN 54-1: 2014 "Fire alarm and warning systems". Part 1. Introduction. [Electronic resource]. URL: http://online.budstandart.com/ua/catalog/doc-page.html?id_doc=63092.

2. DBN B.2.5-56: 2014 "Fire protection systems". [Electronic resource]. URL: http://kbu.org.ua/assets/app/documents/dbn2/98.1.\%20ДБН\%20В.2.5 -56 2014.

3. Fire alarm control panels “Tiras-4P”, “Tiras-8P”. Manual operation. AAZCH. 4225521.003 RE. [Electronic resource]. URL: https://tiras.ua/ru/tiras-4p.

4. Alarm control and security device VERS-PC (8, 4, 2). Operation manual, passport VERS.425713.119RE. [Electronic resource]. URL: http://www.verspk.ru/files/flib/1600.pdf.

5. Alarm control and security device “Arton-08P”. Passport MCI 425513.003PS. [Electronic resource]. URL: https://arton.com.ua/files/passports/new_pas_dec13_arton-08f.pdf.

6. Thermal fire detector SPT-Tiras. Passport of AAZCH.425212.002-00.02 PS. [Electronic resource]. URL: https://tiras.ua/ru/spt-tiras.

7. Combined fire detector SPK-Tiras. Passport of AAZCH.425238.002-00.01 PS. [Electronic resource]. URL: https://tiras.ua/ru/spk-tiras.

8. Fire smoke detector SPD 2-Tiras. Passport of AAZCH.425232.002-01.01 PS. [Electronic resource]. URL: https://tiras.ua/ru/spd-2-tiras-ex.

9. Fire smoke detector SPD-3. Passport. [Electronic resource]. URL: https://arton.com.ua/products/fire_detectors/conventional_smoke_detectors/spd_3/.

10. Thermal fire detector SPT-2B. Passport MCI 425212.002-01 PS. [Electronic resource]. URL: https://arton.com.ua/files/passports/spt-2b-Xx_2018-10-29.pdf.

11. Fire Heat Detector maximum FT-1AS. Passport of MCI 425212.004-01 PS. [Electronic resource]. URL: https://arton.com.ua/files/ passports/new_pas_ft_s.pdf.

12. Features of construction of fire alarm circuits / T.V. Terletskyi, V.V. Lyubitovets, A.A. Tkachuk, O.L. Kaidik, S.A. Moroz // Scientific notes. Intercollegiate Collection (in the fields of knowledge "Technical Sciences”). - Lutsk: Lutsk NTU, 2019. - №65. - P. 254-261. 